\title{
Evaluation of the efficiency of the sewage treatment plant from the University of Santa Cruz do Sul (UNISC), RS, Brazil
}

\author{
Avaliação da eficiência da estação de tratamento de esgoto da \\ Universidade de Santa Cruz do Sul (UNISC), RS, Brasil
}

\section{Adriana Düpont and Eduardo Alcayaga Lobo}

\section{Department of Biology and Pharmacy, University of Santa Cruz do Sul - UNISC, Av. Independência, 2293, CEP 96815-900, Santa Cruz do Sul, RS, Brazil e-mail: adrianad@unisc.br; lobo@unisc.br}

\begin{abstract}
Aim: The main objective was to evaluate the efficiency of the sewage treatment plant (STP) of UNISC, through the ecotoxicological characterization and the analyses of the physical, chemical and microbiological variables from the raw and treated effluent. Methods: Samples were collected during 2008 and 2009 for performing acute toxicity (Daphnia magna), chronic toxicity (Ceriodaphnia dubia), as well as the determination of environmental variables. Results: The results indicated acute toxicity with an EC(I) 5048 hours average of $64.1 \pm 9.9 \%$, characterized as moderately toxic, and an average chronic toxicity $\mathrm{CI}(\mathrm{I}) 25$ of $8,1 \pm 2.6 \%$, characterized as highly toxic. The total phosphorus $\left(3.6 \pm 1.4 \mathrm{mg} \mathrm{L}^{-1}\right)$ and the ammonia nitrogen $\left(77.8 \pm 22.5 \mathrm{mg} \mathrm{L}^{-1}\right)$ showed high concentration in the treated effluent, highlighting the STP inefficiency and, specially, the large amount of nutrients that the system is introducing into the receiving waterbody, the Lajeado Stream, condition that characterizes a large potential environmental impact known as eutrophication. The treated effluent showed high levels of thermotolerant coliforms, reaching an average of $6.4 \times 10^{5} \pm 8.6 \times 10^{5} \mathrm{NMP} 100 \mathrm{~mL}^{-1}$, corresponding to a potential pollution load of high impact in the receiving waterbody, characterizing therefore a public health problem. Conclusions: The Lajeado Stream has no supporting capacity for preventing acute and chronic effects on biota.
\end{abstract}

Keywords: sewage treatment plant, quality of treated effluent, Daphnia magna, Ceriodaphnia dubia.

Resumo: Objetivo: O principal objetivo foi avaliar a eficiência da estaçấo de tratamento de efluentes (ETE) da UNISC, através da caracterização ecotoxicológica e de análises das variáveis físicas, químicas e microbiológicas do efluente bruto e tratado. Métodos: Amostras foram coletadas em 2008 e 2009, para a realização de ensaios de toxicidade aguda (Daphnia magna) e toxicidade crônica (Ceriodaphnia dubia), além da determinação de variáveis ambientais. Resultados: Os resultados indicaram toxicidade aguda, com uma CE(I)50 48 horas média de 64,1 $\pm 9,9 \%$, caracterizada como medianamente tóxica, e uma toxicidade crônica média $\mathrm{CI}(\mathrm{I}) 25$ de $8,1 \pm 2,6 \%$, caracterizada como extremamente tóxica. As variáveis fósforo total $\left(3,6 \pm 1,4 \mathrm{mg} \mathrm{L}^{-1}\right)$ e nitrogênio amoniacal $\left(77,8 \pm 22,5 \mathrm{mg} \mathrm{L}^{-1}\right)$, apresentaram altas concentraçôes no efluente tratado demonstrando a ineficiência da ETE e, principalmente, o grande aporte de nutrientes que o sistema lança ao corpo receptor, o Arroio Lajeado, condição que caracteriza um grande impacto ambiental potencial conhecido como eutrofização. $\mathrm{O}$ efluente tratado apresentou índices elevados de coliformes termotolerantes, atingindo um valor médio de $6,4 \times 10^{5} \pm 8,6 \times 10^{5} \mathrm{NMP} 100 \mathrm{~mL}^{-1}$, correspondendo a uma carga poluidora potencial de alto impacto, caracterizando portanto um problema de Saúde Pública. Conclusóes: O Arroio Lajeado não apresenta capacidade de suporte que permita prever efeitos agudos e crônicos à biota.

Palavras-chave: estação de tratamento de esgoto, qualidade do efluente tratado, Daphnia magna, Ceriodaphnia dubia. 


\section{Introduction}

The generation of domestic or industrial wastes by man as well as the application of pesticides in soil, contributes to the introduction of compounds in the water, affecting its quality (Sperling, 2005).

In relation to the environmental laws for the State of Rio Grande do Sul, the resolution 128 of the Environmental State Council (Rio Grande do Sul, 2006a) determines the emission standards for wastewater sources to be discharged into the receiving water bodies. Yet, the resolution 129 (Rio Grande do Sul, 2006b), provides the definition of criteria and emission standards for toxicity of effluents released to surface waters. These environmental resolutions have provided qualitative and quantitative criteria for the actual impact of the effluent to the receiving water body, however, very little is discussed about the carrying capacity of the water body.

Thus, effluent treatment procedures play a fundamental role in the treatment and management of domestic and industrial effluents, in order to meet the official quality standards for the aquatic environment and protect public health. Conventional and advanced sewage treatments are constituted by a combination of different physical, chemical and biological techniques (Tessele, 2010).

The aquatic ecotoxicology is an effective tool to monitoring, prevent and control water quality, especially in environments with contaminants difficult to identify, by measuring the impact of chemicals or complex mixtures on living organisms, utilizing ecotoxicological assays (Almeida et al., 2002).

Thus, aware of the problems arising from water pollution, the University of Santa Cruz do Sul (UNISC) installed a Sewage Treatment Plant (STP) in order to remove nutrients and organic matter. With the Operating License Number, 4584/2007-DL, issued by the State Environmental Protection Institute (FEPAM), the procedure is made through a conventional preliminary treatment; primary treatment that consists in an upflow anaerobic sludge blanket reactor (UASB); secondary treatment, using a biofilter system (BA) followed by a secondary settling tank, with a maximum discharge of $360 \mathrm{~m}^{3}$ day $^{-1}$ considering an estimated population of 18,000 people. The Lajeado stream is the receiving waterbody of the treated effluent through indirect discharge in the rainwater channels. The effluent of the university campus is composed of black and yellow waters coming from the toilets; the urine is the main residue, considering an average floating population of 11,500 individuals per semester.

In this context, the objective of the present study was to evaluate the efficiency of the Sewage Treatment Plant (STP) from the University of Santa Cruz do Sul (UNISC), RS, Brazil, through the ecotoxicological characterization and the analyses of the physical, chemical and microbiological variables from the raw and treated effluent.

\section{Material and Methods}

The raw effluent samples were collected in the STP after the screening procedure in the preliminary treatment, and the treated effluent in the inspection box after the secondary treatment, from November to December 2008 and March to August 2009, totalizing 36 samples for acute toxicity tests (18 samples for each type of effluent) and 28 samples for chronic toxicity tests (14 samples for each type of effluent). For the physical, chemical and microbiological analyses, 10 samples were collected (five samples for each type of effluent). For the microbiological analyses, the group of thermotolerant coliforms was used and the results were expressed as Most Probable Number MPN $100 \mathrm{~mL}^{-1}$ (Silva et al., 2000). The methodology used for acute toxicity with Daphnia magna followed the Brazilian standard NBR 12713 (ABNT, 2004). The results were expressed as EC(I) 5048 hours, the concentration of the sample at the beginning of the test, which causes acute effect of $50 \%$ of exposed organisms in 48 hours (Hamilton, 1979). The results of the acute toxicity tests were classified using a relative toxicity scale proposed by Lobo et al. (2006), (Table 1).

The methodology used for chronic toxicity with Ceriodaphnia dubia followed the Brazilian standard 13373 (ABNT, 2005). For statistical calculations, the criteria of reproduction and mortality were considered (Norberg King, 1993). The results were expressed as IC(I) 25, nominal concentration of the sample which cause a reduction of $25 \%$ percentage in the reproduction of the test organisms compared to control. Like the acute toxicity assay, the results of chronic toxicity tests were also classified using the relative toxicity scale adapted from Lobo et al. (2006).

The following physical and chemical parameters were used for environmental assessment: biochemical oxygen demand in 5 days $\left(\mathrm{BOD}_{5}, \mathrm{mg} \mathrm{L}^{-1}\right)$, chemical oxygen demand (COD, $\left.\mathrm{mg} \mathrm{L}^{-1}\right)$, total phosphorus ( $\left.\mathrm{mg} \mathrm{L}^{-1}\right)$, ammonia nitrogen $\left(\mathrm{mg} \mathrm{L}^{-1}\right)$, $\mathrm{pH}$, oils and fats $\left(\mathrm{mg} \mathrm{L}^{-1}\right)$, suspended solids $\left(\mathrm{mg} \mathrm{L}^{-1}\right)$ and 
temperature $\left({ }^{\circ} \mathrm{C}\right)$. The analytical procedures are described in APHA (2005).

To estimate the potential environmental impact of the treated effluent into the receiving waterbody, the Lajeado Stream, the methodology described in CETESB (1992) was used, which considers situations of dry weather, that is, minimum flowrate of 7 days and turnaround time of 10 years $\left(\mathrm{Q}_{7,10}\right)$. The discharge $\left(\mathrm{Q}_{7,10}\right)$ has been used as reference in studies to define criteria for toxic effluents emissions. The flowrate of Lajeado Stream corresponds to $588.2 \mathrm{~m}^{3}$ day $^{-1}$, determined by the Laboratory of Limnology of UNISC based on NWA (2010). The load carrying capacity of Lajeado Stream was determined after performing the calculation of the concentration of the effluent in the receiving waterbody, known as WBEC, established by Equation 1, where $\mathrm{Q}_{\mathrm{e}}$ represents the flow of the effluent from the STP, and $\mathrm{Q}_{7,10}$, the minimum flowrate of 7 days and turnaround time of 10 years of Lajeado Stream.

$\mathrm{WBEC}=\frac{\mathrm{Q}_{\mathrm{e}}}{\mathrm{Q}_{7,10}+\mathrm{Q}_{\mathrm{e}}} \times 100$

For the acute toxicity test, CETESB (1992) determines that at the level of $1 / 3$ of the EC(I) 50 48 hours, the toxic effects are nulls. Moreover, it considers that the relationship between the EC(I) 50 48 hours and NOEC(I) is typically on the order of $1 / 10$ for preventing chronic effects. Thus, the concentration of the treated effluent to prevent acute effect (WBEC-AE) was estimated according to Equation 2, and to prevent chronic effects (WBEC$\mathrm{CE})$, using Equation 3.
WBEC $-\mathrm{AE} \leq \frac{\mathrm{EC} 50}{300}$

WBEC $-\mathrm{CE} \leq \frac{\mathrm{EC} 50}{1000}$

The ideal flow of Lajeado stream for receiving the treated effluent was estimated according to Equation 4, where (WBEC-CE) represents the value calculated to prevent chronic effects. $\mathrm{Q}_{\mathrm{e}}$ represents the flow of the effluent from the STP, and $Q_{7,10}$, the minimum flowrate of 7 days and turnaround time of 10 years of Lajeado Stream.

$\mathrm{WBEC}-\mathrm{CE}=\frac{\mathrm{Q}_{\mathrm{e}}}{\mathrm{Q}_{7,10}+\mathrm{Q}_{\mathrm{e}}} \times 100$

\section{Results and Discussion}

Considering the total sampling period for the acute toxicity tests with Daphnia magna, September was the month in which there was a significant reduction of toxicity (Figure 1), from highly toxic to moderately toxic, showing a better efficiency in relation to the processes used. In the other months, however, the detoxification process showed no efficiency because it was not observed

Table 1. Scale of relative toxicity for acute test using Daphnia magna, proposed by Lobo et al. (2006).

\begin{tabular}{ccl}
\hline Percentil & $\mathbf{E C}(\mathbf{I} \mathbf{5 0} \mathbf{4 8}$ hours & \multicolumn{1}{c}{ Toxicity } \\
\hline $25^{\circ}$ & $<25 \%$ & Extremely toxic \\
$50^{\circ}$ & $25-50 \%$ & Highly toxic \\
$75^{\circ}$ & $50-75 \%$ & Moderately toxic \\
- & $>75 \%$ & Low toxic \\
\hline
\end{tabular}

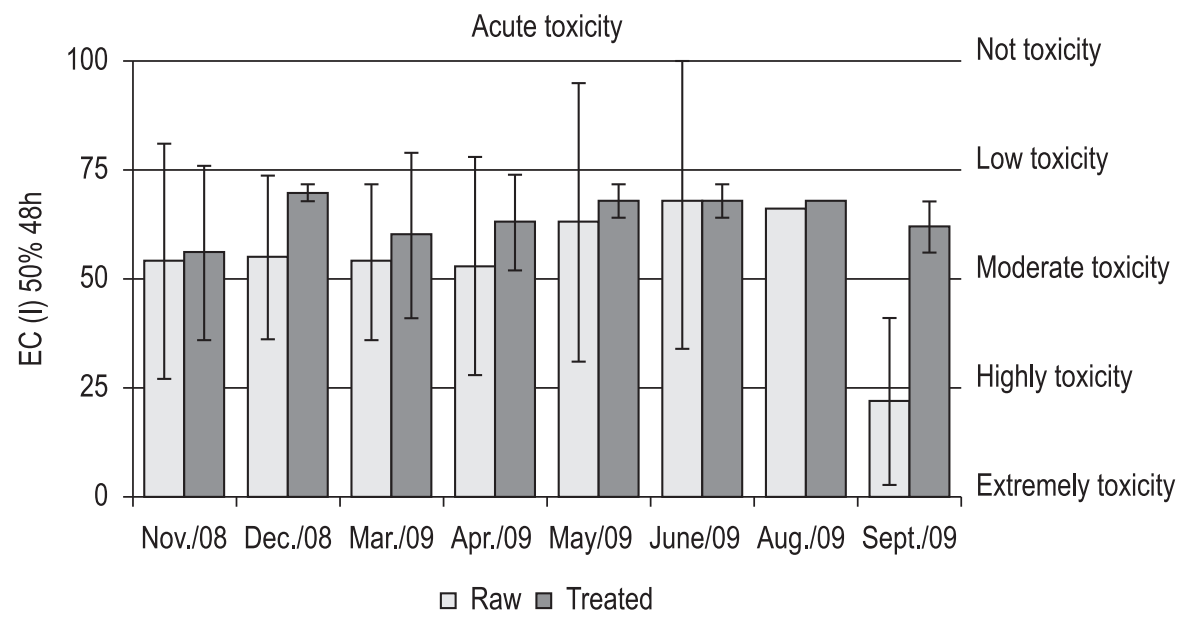

Figure 1. Results of acute toxicity (mean \pm standard deviation) for the raw and treated effluent from the STP, for all the months studied. 
a significant reduction of toxicity, since both raw and treated effluents were classified as moderately toxic. From the point of view of acute ecotoxicology, the results indicated the need for adjustments in the operational processes UASB and BA, as they proved to be inefficient compared to the raw effluent toxicity.

In a research conducted in 2007, Colletta (2008) evaluated the efficiency of detoxification of the effluent from the STP using Daphnia magna as test-organism. The results indicated inefficiency in the operational processes, since the raw effluent toxicity showed variations between moderately toxic to highly toxic levels while the treated effluent was classified as moderately toxic. In this way, the results from Colletta (2008) and those obtained in this study show that over the last two years there was no improvement in the efficiency of detoxification processes from STP.

With regard to chronic toxicity for all the months studied, the UASB and BA processes were inefficient to removal toxicity, since both raw and treated effluents were extremely toxic to Ceriodaphnia dubia (Figure 2).

Similarly, Colletta (2008) found out in a chronic toxicity study, performed in the same sewage treatment plant, that the raw and treated effluent were also classified as extremely toxic to the test-organism Scenedesmus subspicatus, an alga (Chlorophyceae) representing the trophic level of producers. Hamada (2008), after evaluating the sewage treatment plant of Suzano region, SP, which receives industrial effluents and domestic sewage from five counties, also verified extreme chronic toxicity in the treated effluent $(7.1 \%)$ using Ceriodaphnia dubia as a test-organism.

Thus, the UASB and BA operational processes utilized in the STP were inefficient for detoxification purposes, having caused acute toxicity to Daphnia magna and chronic toxicity to Ceriodaphnia dubia, classifying the STP as moderately toxic and extremely toxic, respectively.

For an overall assessment of the raw and treated effluent, together with the ecotoxicological approach, physical and chemical analysis were carried out from March to August 2009, using as criteria for evaluation the CONAMA resolution 357 (Brasil, 2005) and the CONSEMA resolution 128 (Rio Grande do Sul, 2006a). The results indicated that the parameters $\mathrm{BOD}_{5}\left(\mathrm{mg} \mathrm{L}^{-1}\right)$, COD $\left(\mathrm{mg} \mathrm{L}^{-1}\right)$, oils and fats $\left(\mathrm{mg} \mathrm{L}^{-1}\right)$, suspended solids $\left(\mathrm{mg} \mathrm{L}^{-1}\right)$, temperature $\left({ }^{\circ} \mathrm{C}\right)$ and $\mathrm{pH}$ were in accordance with the existing legal standards.

About total phosphorus (Figure 3), the resolution CONSEMA 128 (Rio Grande do Sul, 2006a) determines only maximum values for domestic wastewater with a discharge starting from $1000 \mathrm{~m}^{3}$ day $^{-1}$, however, the STP of UNISC have a discharge of 70 to $120 \mathrm{~m}^{3} \mathrm{day}^{-1}$. Even thus, the average concentration of total phosphorus in the treated effluent was $3.6 \pm 1.4 \mathrm{mg} \mathrm{L}^{-1}$, higher than the maximum allowed by CONSEMA's resolution, $3.0 \mathrm{mg} \mathrm{L}^{-1}$, assuming a maximum flow of $1000 \leq \mathrm{Q} \leq 2000 \mathrm{~m}^{3} \mathrm{day}^{-1}$. Colletta (2008) showed similar results, in which the average concentration of total phosphorus in the treated effluent was $4.8 \pm 1.6 \mathrm{mg} \mathrm{L}^{-1}$.

In a general way, the results indicated that the values obtained for total phosphorus in the treated

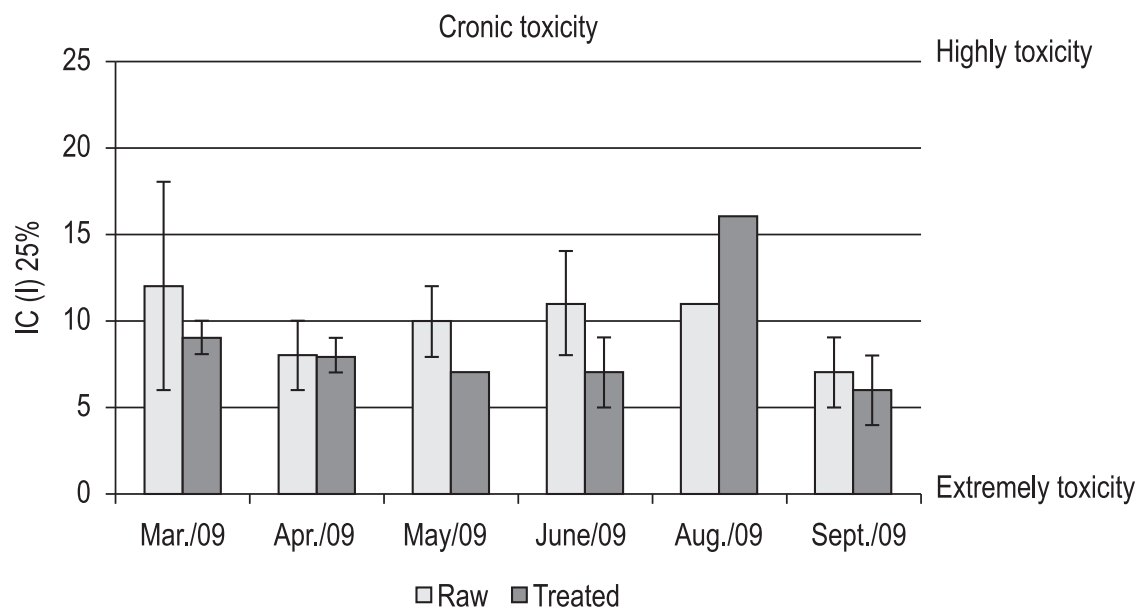

Figure 2. Results of chronic toxicity (mean \pm standard deviation) for the raw and treated effluent from the STP, for all the months studied. 
effluent are not in accordance with the existing legal standards. The inefficiency for this nutrient removal by UASB and BA processes has been discussed in the scientific literature (e.g., Chernicharo, 2006), which points out that these processes show an average phosphorus removal $<35 \%$. Sperling (1996) mentions removal efficiency from 10 to $20 \%$ for total phosphorus in domestic sewage using the UASB treatment.

High concentrations of total phosphorus in the order of 1 to $8 \mathrm{mg} \mathrm{L}^{-1}$ were also observed by Oliveira and Sperling (2005), after the evaluation of treated effluent by UASB. Similarly, Souza (1996) noted a high concentration of phosphorus ranging from 5.6 to $7.0 \mathrm{mg} \mathrm{L}^{-1}$ for treated effluent by UASB. Yet, Bertolino et al. (2008) showed that the effluent from the Federal University of Ouro Preto, MG, has a typical characteristic of domestic sewage, with an average value for total phosphorus of $6 \mathrm{mg} \mathrm{L}^{-1}$, probably related to the complex nature of substances that are released from the laboratories of the university campus along with the sewer.

About the ammonia parameter (Figure 4), it was found that the average concentration in the treated effluent was $77.8 \pm 22.5 \mathrm{mg} \mathrm{L}^{-1}$. The resolution CONSEMA 128 determines that for any effluent the discharge must be met the standard of $20 \mathrm{mg} \mathrm{L}^{-1}$. Thus, it was found that all samples of the treated effluent showed values above the recommended, demonstrating not only the inefficiency of the STP in removing ammonia nitrogen, but mainly the large amount of nitrogen that the treatment plant discharges into the receiving waterbody. Colletta (2008) showed similar results, where the average concentration of ammonia nitrogen in the treated effluent of STP was $40.1 \pm 17.3 \mathrm{mg} \mathrm{L}^{-1}$.
In fresh sewage, about $60 \%$ of the nitrogen is present in the form of organic nitrogen and $40 \%$ in the form of ammonia (Jenkins and Hermanowicz, 1991). Adamson et al. (1998) found that ammonia and nitrite were present in concentrations high enough to cause toxic effects to Daphnia magna in a treatment system for aquaculture. Emmanuel et al. (2005) detected high levels of ammonia nitrogen in effluent samples from hospital, which is toxic to aquatic organisms in concentrations $\geq 1,0 \mathrm{mg} \mathrm{L}^{-1}$.

Kallquist and Svenson (2003) determined the toxicity of ammonia to the unicellular alga Nephroselmis pyriformis, identifying the compound as a dominant toxic industrial effluent. Huddleston et al. (2000) also observed that with decreasing concentration of ammonia in the effluent by $95 \%$, the survival of Pimephales promelas and Ceriodaphnia dubia increased $50 \%$ and $25 \%$, respectively.

In general, high concentrations of total phosphorus in the treated effluent and especially the concentration of ammonia nitrogen, demonstrate not only the inefficiency for these compounds removal, but mainly the large amount of phosphorus and nitrogen discharged into the receiver waterbody. This condition characterizes a large environmental potential impact known as eutrophication.

Regarding the parameter thermotolerant coliforms, it was found that the treated effluent showed extremely high levels, reaching an average of $6.4 \times 105 \pm 8.6 \times 105 \mathrm{MPN} 100 \mathrm{~mL}^{-1}$, corresponding to a potential pollution load of high impact that characterizes a public health problem. The CONSEMA resolution 128 does not establish maximum allowable values for this variable; however, inferences can be made about the water quality of the receiving waterbody by means of

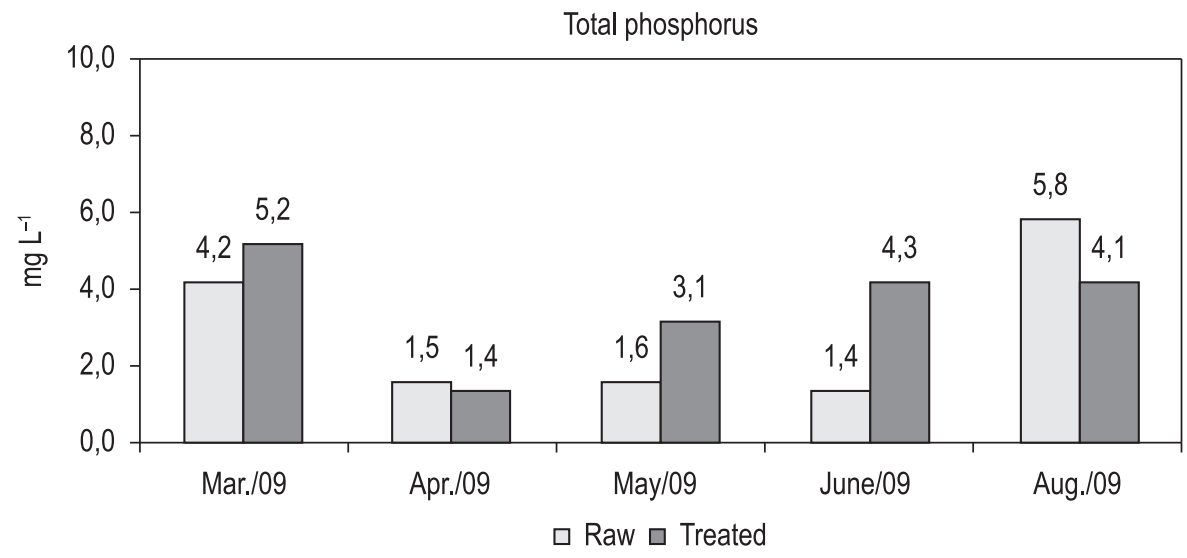

Figure 3. Results for total phosphorus $\left(\mathrm{mg} \mathrm{L}^{-1}\right)$ in the raw and treated effluent from the STP, for all the months studied. 
CONAMA resolution 357 . The threshold value that this resolution sets out to differentiate the Water Use Class "3", from the Water Use Class " 4 ", corresponding to the class of worst quality, is $4.0 \times 10^{3} \mathrm{MPN} 100 \mathrm{~mL}^{-1}$, becoming evident that a concentration of coliforms as high as the observed value, presents a significant environmental impact.

The estimation of the environmental impact of the treated effluent, in each month studied, was made based on the results of the EC(I) 50 48 hours. Table 2 presents the ecotoxicological characteristics of the effluent, highlighting the values of acute toxicity (EC(I) 5048 hours \%), the minimum flowrate of 7 days and turnaround time of 10 years $\left(\mathrm{Q}_{710}\right)$, maximum release flow of treated effluent (Q), the supporting capacity of Lajeado stream calculated through the concentration of the effluent in the receiving waterbody (WBEC), the concentration of the effluent in the receiving waterbody to prevent acute effect (WBEC-AE), the concentration of the effluent in the receiving waterbody to prevent chronic effect (WBEC-CE) and also the ideal flow $\left(\mathrm{Q}_{\mathrm{e}}\right.$ ideal $)$.

The results indicated that the treated effluent showed acute and chronic risks to the ecosystem of the Lajeado Stream, in all months studied, since the values obtained to prevent acute effect (WBEC-AE) and chronic effect (WBEC-CE) were lower than the concentration of the effluent in the receiving waterbody (WBEC), according to the limit set by CETESB (1992). Thus, there is no compatibility between the effluent generated by the STP of UNISC and the water quality of the Lajeado Stream, since the low water level of the receiving waterbody did not supports such kind of impacts. The ideal flow rate calculated for the treated effluent in order to prevent acute and chronic effects in the receiving waterbody showed an average value of

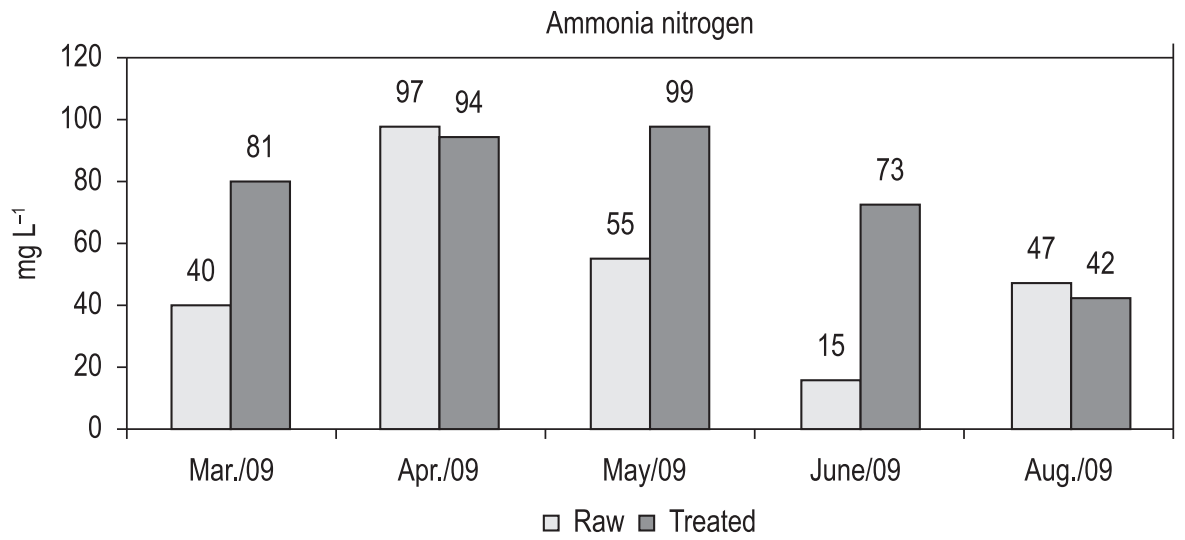

Figure 4. Results for ammonia nitrogen $\left(\mathrm{mg} \mathrm{L}^{-1}\right)$ in the raw and treated effluent from the STP, for all the months studied.

Table 2. Environmental impact assessment of the Lajeado Stream following CETESB (1992).

\begin{tabular}{lccccccc}
\hline Date & $\begin{array}{c}\mathbf{C E}(\mathbf{l}) \mathbf{5 0} \\
\mathbf{4 8} \text { hours (\%) }\end{array}$ & $\begin{array}{c}\mathbf{Q}_{\mathbf{7}, 10} \\
\mathbf{m}^{3} \mathbf{d a y}^{-1}\end{array}$ & $\begin{array}{c}\mathbf{Q}_{\mathrm{e}} \\
\mathbf{m}^{3} \mathbf{d a y}^{-1}\end{array}$ & WBEC (\%) & $\begin{array}{c}\text { WBEC-AE } \\
(\%)\end{array}$ & $\begin{array}{c}\text { WBEC- CE } \\
(\%)\end{array}$ & $\begin{array}{c}\mathbf{Q}_{\mathrm{e}} \text { ideal } \\
\mathbf{m}^{3} \text { day }^{-1}\end{array}$ \\
\hline Nov. 08 & 56 & 588.2 & 120 & 16.94 & 0.186 & 0.056 & 0.329 \\
Dec. 08 & 70 & 588.2 & 120 & 16.94 & 0.233 & 0.070 & 0.411 \\
Mar. 09 & 60 & 588.2 & 120 & 16.94 & 0.200 & 0.060 & 0.353 \\
Apr. 09 & 63 & 588.2 & 120 & 16.94 & 0.210 & 0.063 & 0.370 \\
May 09 & 68 & 588.2 & 120 & 16.94 & 0.226 & 0.068 & 0.400 \\
June 09 & 65 & 588.2 & 120 & 16.94 & 0.216 & 0.065 & 0.382 \\
Aug. 09 & 68 & 588.2 & 120 & 16.94 & 0.226 & 0.068 & 0.400 \\
Sept. 09 & 62 & 588.2 & 120 & 16.94 & 0.206 & 0.062 & 0.364 \\
\hline
\end{tabular}

$\mathrm{CE}(\mathrm{I})_{50} 48$ hours: concentration of the sample at the beginning of the test, which causes acute effect of $50 \%$ of exposed organisms in 48 hours; $\left(\mathrm{Q}_{\mathrm{e}}\right) \mathrm{m}^{3} \mathrm{day}^{-1}$ : Maximum release flow of treated effluent in $\mathrm{m}^{3} \mathrm{day}^{-1} ; \mathrm{Q}_{7,10} \mathrm{~m}^{3} \mathrm{day}^{-1}$ : Minimum flowrate of 7 days and turnaround time of 10 years in $\mathrm{m}^{3}$ day $^{-1}$; WBEC: Concentration of the effluent in the receiving waterbody; WBEC-AE: Concentration of the effluent in the receiving waterbody to prevent acute effect; WBEC-CE: Concentration of the effluent in the receiving waterbody to prevent chronic effect; $\left(\mathrm{Q}_{\mathrm{e}} \mathrm{ideal}^{3} \mathrm{day}^{-1}\right)$ : Ideal flow for the Lajeado stream in $\mathrm{m}^{3}$ day $^{-1}$. 
$0.38 \pm 0.03 \mathrm{~m}^{3} \mathrm{day}^{-1}$, meanwhile the actual flow rate of the effluent corresponds to $120.0 \mathrm{~m}^{3}$ day $^{-1}$; consequently, the receiving waterbody does not have the supporting capacity that allows to prevent acute and chronic effects to biota.

Costa and Dalberto (2009) reported similar results after evaluation of the carrying capacity of the Pardinho River, RS, with a discharge rate of $25,747.2 \mathrm{~m}^{3} \mathrm{day}^{-1}$, for treated effluents as follows: wastewater treatment of domestic sewage (flow of $670 \mathrm{~m}^{3} \mathrm{day}^{-1}$ ), swine fridge (flow of $360 \mathrm{~m}^{3}$ day $^{-1}$ ), food industry/pasta and biscuits (flow of $40 \mathrm{~m}^{3}$ day $^{-1}$ ), leather tanning industry (flow of $432 \mathrm{~m}^{3}$ day $^{-1}$ ), textile industry (flow of $40 \mathrm{~m}^{3}$ day $^{-1}$ ) and hospital laundry (flow of $50 \mathrm{~m}^{3}$ day $^{-1}$ ). It was found that all effluents evaluated resulted in acute and chronic risks to biota of Pardinho River even released separately in the receiving body. The ideal flow rate calculated for each effluent was: wastewater treatment of domestic sewage $\left(17.0 \mathrm{~m}^{3} \mathrm{day}^{-1}\right)$, swine fridge $\left(25.8 \mathrm{~m}^{3} \mathrm{day}^{-1}\right)$, food industry/pasta and biscuits $\left(25.8 \mathrm{~m}^{3}\right.$ day $\left.^{-1}\right)$, leather tanning industry $\left(2.3 \mathrm{~m}^{3}\right.$ day $\left.^{-1}\right)$, textile industry $\left(13.9 \mathrm{~m}^{3}\right.$ day $\left.^{-1}\right)$ and hospital laundry $\left(0.2 \mathrm{~m}^{3}\right.$ day $\left.^{-1}\right)$.

Integrating all the information, it was found that in relation to environmental impact, there is a potential risk in terms of acute and chronic toxic effects, nutrients and thermotolerant coliforms, since the Lajeado Stream does not show the carrying capacity to support this kind of impacts. The results indicate the need for adjustments in the operational processes of the STP from UNISC, since they have shown inefficient operating conditions.

\section{References}

ADAMSON, M., DAVE, G., FORSBERG, L. and GUTERSTAM, B. 1998. Toxicity identification and evaluation of ammonia, nitrite and heavy metals at the Stensund Wastewater Aquaculture plant, Sweden. Water Science and Technology, vol. 38, no. 3, p. 151-157. http://dx.doi.org/10.1016/S02731223(98)00459-4

ALMEIDA, CA., COSTA, JB. and BERNI, CR. 2002. Uma abordagem alternativa para análises estatística dos resultados de testes de toxicidade crônica. In ESPÍNDOLA, ELG., PASCHOAL, CMRB., ROCHA, O., BOHRER, MBC. and OLIVEIRA NETO, AL., org. Ecotoxicologia perspectivas para $o$ século XXI. São Carlos: Rima. p. 501-520.

American Public Health Association - APHA. 2005. Standard Methods for the Examination of Water and wastewater. 20th ed. Washington: APHA.

Associação Brasileira de Normas Técnicas - ABNT. 2005. NBR 13373: Ecotoxicologia aquática - Toxicidade crônica - Método de ensaio com Ceriodaphnia spp. (Crustácea, Cladócera). 2. ed. ABNT.

Associação Brasileira de Normas Técnicas - ABNT. 2004. NBR 12713: Ecotoxicologia aquática - Toxicidade aguda - Método de ensaio com Daphnia spp. (Cladócera, Crustácea). 2. ed. ABNT.

BERTOLINO, SM., CARVALHO, CF. and AQUINO, SF. 2008. Caracterização e biodegrabilidade anaeróbia e anaeróbia dos esgotos. Revista Engenharia Sanitária Ambiental, vol.13, p. 271-277.

Brasil. Conselho Nacional do Meio Ambiente CONAMA. 2005. Resolução 357, de 17 de março de 2005. Dispóe sobre a classificação dos corpos de água e diretrizes ambientais para seu enquadramento, bem como estabelece as condiçóes e padrôes de lançamento de efluentes, e dá outras providencias. Diário Oficial da República Federativa do Brasil, Brasília, DF, mar. 2005. Available from: <http://www. mma.gov.br>. Acess in: 17 abr. 2005.

CHERNICHARO, CAL. 2006. Pós tratamento de efluentes de reatores anaeróbicos. Rio de Janeiro: PROSAB/FINEP. 544 p.

COLLETTA, VD. 2008. Avaliação ecotoxicológica da eficiência da detoxificação do efluente tratado pela estação de tratamento de esgoto da Universidade de Santa Cruz do Sul, RS, Brasil. Santa Cruz do Sul: Universidade de Santa Cruz do Sul. [Dissertação de Mestrado em Tecnologia Ambiental na Área de Concentração em Gestão e Tecnologia Ambiental].

Companhia de Tecnologia de Saneamento Ambiental CETESB. 1992. Métodos de avaliação da toxicidade de poluentes de organismos aquáticos. São Paulo: CETESB. 312 p.

COSTA, AB. and DALBERTO, D. 2009. Avaliação da compatibilidade entre processos produtivos e os ecossistemas locais pela determinação da capacidade suporte dos recursos hídricos. In Anais do XXIX Encontro Nacional de Engenharias de Produção: A engenharia de produçáo e o desenvolvimento Sustentável: Integrando Tecnologia e Gestão, 2009. Salvador.

EMMANUEL, E., PERRODIN, Y., KECK, G., BLANCHARD, JM. and VERMANDE, P. 2005. Ecotoxicological risk assessment of hospital wastewater: a proposed framework for raw effluents discharging into urban sewer network. Journal of Hazardous Materials, vol. 117, p. 1-11.

HAMADA, N. 2008. Ensaios de toxicidade empregados na avaliação de efeitos no sistema de tratamento de esgotos e efluentes, ETE Suzano, e seu entorno, utilizando organismos aquáticos. São Paulo: Instituto de Pesquisas Energéticas e Nucleares. [Dissertação de Mestrado].

HAMILTON, MA., RUSSO, RC. and THURSTON, RV. 1979. Trimmed Spearmann-Karber method for calculation of EC50 and LC values in bioassays. (Software). 
HUDDLESTON, GM., GILLESPIE, WB. and RODGERS, JH. 2000. Using constructed wetlands to treat biochemical oxygen demand and ammonia associated with a refinery effluent. Ecotoxicological and Environmental Safety, vol. 45, no. 2, p. 188-193.

JENKINS, D. and HERMANOWICZ, SW. 1991. Principles of chemical phosphate removal. In SEDLAK, RI. Phosphorus and nitrogen removal from municipal wastewater-Principles and Practice. 2nd ed. New York: Lewis Publishers.

KALLQVIST, T. and SVENSON, A. 2003. Assessment of ammonia toxicity in tests with the microalga, Nephroselmis pyriformis, Chlorophyta. Water Research, vol. 37, no. 3, p. 477-484. Pmid:12688681. http:// dx.doi.org/10.1016/S0043-1354(02)00361-5

LOBO, EA., RATHKE, FS. and BRENTANO, DM. 2006. Ecotoxicologia aplicada: o caso dos produtores de tabaco na bacia hidrográfica do Rio Pardinho, RS, Brasil. In ETGES, VE. and FERREIRA, MAF. A produção do tabaco: impacto no ecossistema e na saúde humana na regiáo de Santa Cruz do Sul/RS. Santa Cruz do Sul: EDUNISC. 248 p., p. 41-68.

NORBERG KING, TJ. 1993. A linear interpolation method for sublethal toxicity: the inhibition concentration (ICp) approach. version 2.0. Duluth: US EPA. (Software).

Nationality Water Agency - NWA. 2010. Available from: <http://hidroweb.ana.gov.br/>. Access in: 24 maio 2010.

OLIVEIRA, SM. and SPERLING, MV. 2005. Avaliação de 166 ETEs em operação no país, compreendendo diversas tecnologias. Parte I - análise de desempenho. Revista de Engenharia Sanitária e Ambiental, vol. 10, n. 4, p. 347-357. http://dx.doi.org/10.1590/S141341522005000400011

Rio Grande do Sul. Secretaria do Meio Ambiente. Conselho Estadual do Meio Ambiente. 2006a. Resolução do Conselho Estadual do Meio Ambiente $n^{\circ} 128$, de 24 de novembro de 2006. Diário Oficial do Rio Grande do Sul, Porto Alegre, nov. 2006.

Rio Grande do Sul. Secretaria do Meio Ambiente. Conselho Estadual do Meio Ambiente. 2006b. Resolução Conselho Estadual do Meio Ambiente $\mathrm{n}^{\circ} 129$, de 24 de novembro de 2006. Diário Oficial do Rio Grande do Sul, Porto Alegre, nov. 2006.

SILVA, N., CANTÚSIO NETO, R., JUNQUEIRA, VCA. and SILVEIRA, NFA. 2000. Manual de métodos de análise microbiológica da água. Campinas: Instituto de Tecnologia de Alimentos. 99 p.

SOUZA, JT. 1996. Pós-tratamento de efluente de reator anaeróbio de fluxo ascendente em reator aeróbio seqüencial em batelada e coluna de lodo anaeróbio para desnitrificação. São Paulo: Universidade de São Paulo. [Tese de Doutorado em Engenharia].

SPERLING, MV. 1996. Introdução à qualidade das águas $e$ ao tratamento de esgotos. 2. ed. Belo Horizonte: Departamento de Engenharia Sanitária e Ambiental, Universidade Federal de Minas Gerais. 243 p.

SPERLING, MV. 2005. Introdução à qualidade das águas e ao tratamento de esgotos. 3. ed. Belo Horizonte: Departamento de Engenharia Sanitária e Ambiental, Universidade Federal de Minas Gerais. 452 p.

TESSELE, F. 2010. Tratamento Otimizado e Reuso de águas residuárias visando a sustentabilidade do meio ambiente. Available from: <http:www.lapes.ufrgs.br/ Itm/pdf/Fabiana.pdf>. Acess in: 19 jul. 2010. 